\title{
Characteristics Defining Broccoli Cultivars from Different Seed Producers
}

\author{
Elena Ordiales, ${ }^{1}$ Domingo J. Iglesias, ${ }^{2}$ María Victoria Alarcón, ${ }^{3}$ Lorena Zajara, ${ }^{1}$ Jesús Gil,, \\ Juan Ignacio Gutiérrez, ${ }^{1}$ and Julio Salguero ${ }^{4}$ \\ ${ }^{1}$ Área de Agricultura, Centro Tecnológico Nacional Agroalimentario Extremadura (CTAEX), 06195 Villafranco del Guadiana, \\ Badajoz, Spain \\ ${ }^{2}$ Departamento de Genómica y Postcosecha, Instituto Valenciano de Investigaciones Agrarias (IVIA), Moncada, 46113 Valencia, Spain \\ ${ }^{3}$ Departamento de Hortofruticultura, Centro de Investigación "La Orden-Valdesequera" (CICYTEX), \\ Junta de Extremadura, Guadajira, 06187 Badajoz, Spain \\ ${ }^{4}$ Departamento de Biología Vegetal, Ecología y Ciencias de la Tierra, Universidad de Extremadura, 06071 Badajoz, Spain
}

Correspondence should be addressed to Julio Salguero; salguero@unex.es

Received 6 March 2017; Accepted 24 July 2017; Published 28 August 2017

Academic Editor: Chandrakanth Emani

Copyright (C) 2017 Elena Ordiales et al. This is an open access article distributed under the Creative Commons Attribution License, which permits unrestricted use, distribution, and reproduction in any medium, provided the original work is properly cited.

\begin{abstract}
Broccoli (Brassica oleracea L. var. italica) is currently considered a main vegetable food in the markets due to its high nutritional value, containing elevated levels of phytochemicals widely described to have beneficial effects against cancer and other illnesses. Broccoli is an interesting crop with a high commercial value because it complements the tomato industry, the main agricultural income in Badajoz, Spain. Nine varieties of broccoli from four nurseries were evaluated by analyzing both agronomic and quality parameters. Total yield and number of harvests were monitored. Parameters defining quality like diameter, weight, and height of the heads were determined. Granulometry, compactness, and the presence of internal leaves in the heads were also analyzed. Diameter and height of sprouts were complementarily estimated. Principal component analysis was further employed to investigate the relationship between the agronomic variables and the cultivars and nurseries. Results revealed that both first and second principal components explained more than $75 \%$ of the variance and grouped data according their cultivar and commercial origin. Additionally, correlations between the scores of those components and the values of the phenotypic parameters suggested that head weights are main determinants of the phenotypic differences observed among the cultivars whereas the presence of internal leaves and granulometry and head weight appear to be key traits defining nurseries.
\end{abstract}

\section{Introduction}

In the last years, agricultural income has considerably declined; therefore producers are searching for new or alternative crops. Spanish consumers are becoming more aware of nutritional value of broccoli and other vegetables. Broccoli has been labeled as the highest nutritional value vegetable, due to its composition of some phytochemical compounds, such as glucosinolates and isothiocyanates, with potential effects on preventing several cancer types and other illnesses $[1,2]$. Broccoli is an abundant source of nutrients, including provitamin $\mathrm{A}$ ( $\beta$-carotene), vitamin $\mathrm{C}$ (ascorbate), and vitamin $\mathrm{E}$ (tocopherol) [3]. Consumers are becoming more aware of the nutritional value of broccoli and other vegetables
[4]. For this reason, the demand of broccoli has recently increased.

Nowadays it is becoming easier to buy processed vegetables, especially broccoli as an ingredient, ready to be used in the market, that meet the consumers' demand for healthy but fast food. Particularly, broccoli grown in Badajoz is usually processed in freezer industries, but also for fresh market, so the main quality characteristics of the production are different considering the broccoli's final use.

The traditional crop in the Vegas Bajas of the Guadiana River (Badajoz, Spain) is the processed tomato, grown from April to August. Broccoli originally was a cool-season crop that should be considered to have commercial potential as complementary crop cultivated in fall-winter. Over the last 
TABLE 1: Agronomic characteristics of broccoli cultivars from different nurseries.

\begin{tabular}{|c|c|c|c|c|c|c|}
\hline Cultivar & Nursery & $\begin{array}{c}\text { Total yield } \\
\mathrm{kg} / \mathrm{ha}\end{array}$ & Days to first harvest & Days to $90 \%$ yield $^{1}$ & Harvests $^{2}$ & $\begin{array}{c}\text { Harvest } \\
>10 \%{ }^{3}\end{array}$ \\
\hline CHRONOS & Sakata & $9092 \mathrm{ab}^{4}$ & $63.0 \mathrm{a}$ & $77 \mathrm{a}$ & $8.0 \mathrm{~d}$ & $3.0 \mathrm{a}$ \\
\hline NAXOS & Sakata & $11545 \mathrm{~b}$ & $67.0 \mathrm{~b}$ & $82 \mathrm{~b}$ & $7.0 \mathrm{bc}$ & $4.3 \mathrm{ab}$ \\
\hline PHAROS & Sakata & $8807 \mathrm{ab}$ & $76.0 \mathrm{ef}$ & $98 \mathrm{~d}$ & $6.0 \mathrm{a}$ & $5.0 \mathrm{bcd}$ \\
\hline GUEVARA & Intersemillas & $7228 \mathrm{ab}$ & $71.0 \mathrm{c}$ & $86 c$ & $6.0 \mathrm{a}$ & $4.7 \mathrm{bc}$ \\
\hline ISI $14775 \mathrm{~F} 1$ & Diamond Seeds & $8924 a b$ & $72.0 \mathrm{~cd}$ & $90 \mathrm{c}$ & $6.7 \mathrm{ab}$ & $4.33 \mathrm{ab}$ \\
\hline ISI 14507 F1 & Diamond Seeds & $8563 a b$ & $71.0 \mathrm{c}$ & $88 \mathrm{c}$ & $7.0 \mathrm{bc}$ & $5.0 \mathrm{bcd}$ \\
\hline CODE M RZ & Rijk Zwaan & $6985 \mathrm{ab}$ & $75.0 \mathrm{de}$ & $96.7 \mathrm{~d}$ & $7.7 \mathrm{~cd}$ & $6.3 \mathrm{e}$ \\
\hline CODE F RZ & Rijk Zwaan & $6348 \mathrm{a}$ & $78.3 \mathrm{f}$ & $98 \mathrm{~d}$ & $6.7 \mathrm{ab}$ & $4.6 \mathrm{bc}$ \\
\hline CODE A RZ & Rijk Zwaan & $7016 \mathrm{ab}$ & $74.0 \mathrm{~cd}$ & $95.3 \mathrm{~d}$ & $7.0 \mathrm{bc}$ & $6.0 \mathrm{~cd}$ \\
\hline
\end{tabular}

${ }^{1}$ Days to achieve $90 \%$ of total yield; ${ }^{2}$ number of total harvests; ${ }^{3}$ number of harvests $>10 \%$ of total yield; ${ }^{4}$ in column, values followed by different letters are significantly different at 0.05 .

years in Extremadura (Spain), the broccoli cultivated area has increased. In 2013 the cultivated area reached 1747 hectares, with a total production of 21617 tons of broccoli heads. Hence, broccoli has become the second most important vegetable grown in Extremadura, after processed tomato [5].

A few varieties of broccoli are used in this area and the increasing interest of farmers in this crop makes an agronomic evaluation of a relatively large number of varieties necessary. In this sense, cultivar selection is difficult because very little specific information about the plant material is available. Crop varieties in 1950 had been bred to be adapted to specific regions and a relatively low input agriculture system. However, contemporary cultivars are selected for yield, disease resistance, broad adaptation to high input agriculture systems, and increased "shipability" and self-life [2]. Broccoli yield and head quality attributes should be considered in selecting a broccoli cultivar for a commercial production in a certain area. The parameters used to evaluate the head quality are size, shape, density color, bead size, and the attributes of stem like diameter, shape, and incidence of hollow stem. Yield and quality characteristics were determined by genotype and environmental interaction but were not affected by photoperiod. Quality attributes depend more on the genotype than the environment [6], so the former is important in determining the level of nutrients in a crop cultivar [7].

Currently, broccoli seeds for sprout production have been obtained from different sources [8]. Broccoli hybrids have been produced by crossing two pure inbred lines, each selfincompatible, but cross-compatible with another one [9]. Thus, seeds from a particular supplier are produced by crossing their own inbred lines and therefore different varieties should have similar phenotypic characteristics.

The aim of this study was to describe the yield and quality of nine cultivars of broccoli to find the most suitable cultivar to be grown on the "Vegas Bajas" of the Guadiana River. In addition, using cluster analysis we have studied the qualitative attributes of different varieties provided by several suppliers.

\section{Materials and Methods}

This trial was conducted in 2009 at the experimental fields of Centro Tecnológico Nacional Agroalimentario of Extremadura, Badajoz, Spain. The alluvial soil has a sandy-loam texture, is slightly acidic, and has a low organic material content. The broccoli seeds were supplied for free by international seeds companies, as indicated in Table 1. These cultivars are hybrid, produced by crossing two inbred lines, each selfincompatible but cross-compatible with one another [9].

The broccoli cultivars were seeded in 294-cell trays (3.75 $\times 5.75 \times 5 \mathrm{~cm})$ on 2009 August 4 . Seedlings were grown in greenhouse until the 2-4 leaf stage, under temperature and humidity controlled conditions. Four-week-old broccoli seedlings were transplanted into the field using a mechanical transplanter (Fialho, Tex Driver) on September 4. Plots consisted of four 20-m-long rows of broccoli, spaced $0.75 \mathrm{~m}$ apart, with $0.38 \mathrm{~m}$ between plants within a row, resulting in a plan density of approximately 35000 plants ha ${ }^{-1}$ [10]. The experimental plots were arranged in a randomized completeblock designed with three replications.

The previous crop was processed tomato, established and grown in the spring and early summer. After the tomato harvest the site was disced and rotavated before being transplanted. The soil was fertilized with $140 \mathrm{~kg} \mathrm{~N} \mathrm{ha}^{-1}$, $75 \mathrm{~kg} \mathrm{P} \mathrm{ha}^{-1}$, and $75 \mathrm{~kg} \mathrm{~K} \mathrm{ha}^{-1}$ [11], by applying $500 \mathrm{~kg} \mathrm{ha}^{-1}$ of 8-15-15 fertilizer before being transplanted using a calibrated fertilizer spreader, and $370.5 \mathrm{~kg} \mathrm{ha}^{-1}$ of ammonium nitrate (27\%) as the plants are 20 days old after transplanting. All fertilizers were incorporated with a cultivator.

Irrigation was scheduled to deliver a total of $50 \mathrm{~mm}$ water (including rainfall) each week, based on soil characteristics and local weather conditions. Overhead irrigation was applied, by sprinklers. Weekly water requirements were split over two or three applications per week. Total monthly precipitation and average temperature, along with other meteorological variables, were measured by a weather station belonging to Junta Extremadura weather stations network, 
and located in the area. The data are available daily in its web page. The mean daily air temperature ranged from $20.5^{\circ} \mathrm{C}$ in September to $7.9^{\circ} \mathrm{C}$ in December. Total precipitation was $65.2 \mathrm{~mm}$ during the crop.

Growing conditions were excellent to maintain good crop health throughout the broccoli crop; therefore disease and pest control were not necessary. However, mechanical weed control was performed at the first stage of the crop.

The broccoli harvest began when the head reached a diameter of about $0.15 \mathrm{~m}$ [12], which is considered desirable for the commercial requirements in the area. The heads were harvested manually every 3 or 4 days until all heads were removed, totaling a maximum of 10 harvests.

The following head broccoli quality attributes were analyzed: weight, height, diameter, bead size, compactness, and presence of internal leaves in heads by measurement of 10 heads in each plot and harvest. The total yield was calculated by weighing the total harvested heads. The total weight of heads harvested is an appropriate yield measure for processing broccoli, which is sold by weight. However, fresh market broccoli is sold by the case and the corresponding goal is to maximize the number of marketable heads and bunches rather than the total weight [13].

Bead size was estimated by a visual three-point scale: fine, medium, and thick, the fine bead size being the most appreciated commercially. Numerical values from 1 to 3 were assigned to each point [5]. By a similar method we estimate the head compactness by assigning values from 1 to 3 , with 1 being the most compact, and for the presence or absence of internal leaves we used the values 1 and 2, respectively. Density, the weight/volume ratio, was calculated using the formula weight $(\mathrm{kg}) \times 238.77 /(\text { diameter }(\mathrm{cm}) / 2)^{3}[14]$.

Statistical analyses were performed with SPSS 13.0 (Chicago, Illinois, USA). Within-cultivar comparison of means was performed with one-way ANOVA and Tukey's test. Differences of means with $P<0.05$ were considered to be significant. Principal component analysis was performed on selected variables (Table 6). Component scores and loadings were calculated after unit variance scaling of the variables. When needed, data transformation was performed prior to analyses in order to achieve normality.

\section{Results and Discussion}

Total yields differed between cultivars (Table 1). Total yields range between $11.545 \mathrm{~kg} \mathrm{ha}^{-1}$ (NAXOS) and $6.348 \mathrm{~kg} \mathrm{ha}^{-1}$ (CODE F RZ), which, respectively, showed the highest and the lowest values. Moreover, these yields were significantly different from those estimated for the other seven cultivars.

In general, yield values were comparable to those found in the literature according to the high interannual variability reported $[5,15]$. In addition, the temperatures during the growth period and the time of planting have been demonstrated to affect the quality and development of heads [16]. Our experiments were conducted with seedlings of the same age and at the same time, so these variables do not interfere in this study. Bakker et al. (2009) found that the total fresh weight yield of marketable heads differed with the year but also with the cultivar [13].
The first harvest takes place when heads have reached a diameter greater than $0.15 \mathrm{~m}$. Therefore, the number of days to the first harvest is determined by the earliness of the variety. The earliest cultivar was CHRONOS, needing 63 days from planting to first harvest and the less precocious was CODE F RZ, with 78.3 days (Table 1 ).

The planting density $\left(35,000\right.$ plants $\left.\mathrm{ha}^{-1}\right)$ is an intermediate value which produces the greatest amount of large head/ha and average values of total yield, head diameter, and weight similar to those obtained in other cultivars of broccoli [17].

We have also calculated the number of days required to reach $90 \%$ of total production. The number of days to first harvest and the numbers of days to reach $90 \%$ of total yield were linearly correlated $\left(y=1.563 x-22.34 ; r^{2}=0.951\right)$. This observation suggests that the more precocious cultivar was the first to finish production.

Because harvest is manually performed, a main factor to be considered is the number of harvests, given that a less number of harvests results in reducing costs. Thus, the number of harvests necessary to collect all the plants and the number of harvests represented in excess of $10 \%$ of the total production have been estimated.

These parameters were uncorrelated, certain cultivars showing numerous harvests accompanied with small productions that did not exceed $10 \%$ of total yield. This is especially important when the variety CHRONOS was considered, which showed eight harvests of which only 3 were over $10 \%$ of the total production. This effect was also observed in NAXOS. It seems that these varieties have a higher collection costs, which would discourage its selecting; however these cultivars have the highest total output of all varieties studied (Table 2).

Agronomic traits, including head diameter, weight, and height affect quality directly. Table 3 shows these parameters together with ratios diameter/height and weight/diameter, as measurements of the head shape. High diameter/height and weight/diameter ratios indicated more suitable properties for the industry, showing a shorter stem, which is not profitable in the industry. Head diameter ranges between 0.166 and $0.167 \mathrm{~m}$ (CODE F RZ and CHRONOS) and $0.185 \mathrm{~m}$ (NAXOS and ISI14775 F1) and significant differences have been found between cultivars. The same varieties also presented the minor and major heights. The short head (CODE F RZ) had a length of $0.107 \mathrm{~m}$; the longest NAXOS was with a length of $0.125 \mathrm{~m}$. Regarding weight, ISI14775 F1 and F1 ISI14507 showed the heavier heads with 551 and $549 \mathrm{~g}$. The heads of CODE F RZ and CODE A RZ presented the least weight with 416 and $423 \mathrm{~g}$, respectively. The head weight registered was higher than those reported by Stamatiadis et al. (1999) [18]. These values showed that differences between the different cultivars are by 11,17 , and $32 \%$ in diameter, height, and weight head, respectively. These attributes can be important if the production is targeted to fresh market, as excessive head diameter and enlarged stems affect quality $[19,20]$. For fresh vegetables, the appearance (e.g., color, size, and shape) of the product influences consumer purchasing decisions [21]. Therefore, the visual quality of the heads is crucial for both fresh market and processing broccoli [13]. 
TABLE 2: Cumulative production $\left(\mathrm{kg} \mathrm{ha}^{-1}\right)$ of different cultivars of broccoli.

\begin{tabular}{|c|c|c|c|c|c|c|c|c|c|c|}
\hline Days (harvests) $^{1}$ & $63(1)$ & $67(2)$ & $70(3)$ & $74(4)$ & $77(5)$ & $81(6)$ & $84(7)$ & $88(8)$ & $91(9)$ & $98(10)$ \\
\hline CHRONOS & 543 & 3733 & 6280 & 7528 & $8190^{2}$ & 8588 & 8896 & 9092 & 9092 & 9092 \\
\hline NAXOS & 0 & 753 & 2260 & 5512 & 6979 & 10488 & 11050 & 11545 & 11545 & 11545 \\
\hline PHAROS & 0 & 0 & 0 & 0 & 395 & 1814 & 3022 & 4756 & 5899 & 8807 \\
\hline GUEVARA & 0 & 0 & 404 & 1686 & 3295 & 5291 & 5862 & 7228 & 7228 & 7228 \\
\hline ISI 14775 F1 & 0 & 0 & 57 & 731 & 2058 & 4475 & 5723 & 7241 & 8924 & 8924 \\
\hline ISI 14507 F1 & 0 & 0 & 250 & 1743 & 3505 & 5385 & 6456 & 8307 & 8563 & 8563 \\
\hline CODE M RZ & 0 & 0 & 31 & 250 & 893 & 2144 & 2834 & 4364 & 5140 & 6985 \\
\hline CODE F RZ & 0 & 0 & 0 & 102 & 284 & 975 & 2024 & 3400 & 4634 & 6348 \\
\hline CODE A RZ & 0 & 0 & 0 & 108 & 890 & 3119 & 4637 & 5700 & 6240 & 7016 \\
\hline
\end{tabular}

${ }^{1}$ Days after transplanting. In brackets, number of harvests. ${ }^{2}$ Italic numbers indicate that $90 \%$ of the total yield has been reached.

TABLE 3: Agronomic characteristics of head from nine broccoli cultivars.

\begin{tabular}{|c|c|c|c|c|c|}
\hline Cultivars & $\begin{array}{c}\text { Diameter } \\
(\mathrm{m})\end{array}$ & $\begin{array}{l}\text { Height } \\
(\mathrm{m})\end{array}$ & $\begin{array}{c}\text { Weight } \\
\text { (g) }\end{array}$ & Diameter/height & Weight/diameter \\
\hline CHRONOS & $0.167 \mathrm{ab}^{1}$ & $0.118 \mathrm{de}$ & $448 \mathrm{ab}$ & $1.43 \mathrm{a}$ & $26682 \mathrm{bc}$ \\
\hline NAXOS & $0.185 \mathrm{~d}$ & $0.125 \mathrm{ef}$ & $510 \mathrm{~cd}$ & $1.48 \mathrm{ab}$ & $27651 \mathrm{~cd}$ \\
\hline PHAROS & $0.176 \mathrm{~cd}$ & $0.115 \mathrm{bcd}$ & $521 \mathrm{~cd}$ & $1.55 \mathrm{bcd}$ & 29278 de \\
\hline GUEVARA & $0.174 \mathrm{ab}$ & $0.115 \mathrm{~cd}$ & $513 \mathrm{~cd}$ & $1.52 \mathrm{ab}$ & $29597 \mathrm{de}$ \\
\hline ISI 14775 F1 & $0.185 \mathrm{~d}$ & $0.115 \mathrm{ab}$ & $551 \mathrm{~d}$ & $1.71 \mathrm{e}$ & $30356 \mathrm{e}$ \\
\hline ISI $14507 \mathrm{~F} 1$ & $0.176 \mathrm{abc}$ & $0.115 \mathrm{bcd}$ & $549 \mathrm{~d}$ & $1.54 \mathrm{bcd}$ & $31279 \mathrm{e}$ \\
\hline CODE M RZ & $0.177 \mathrm{bcd}$ & $0.110 \mathrm{abc}$ & $485 \mathrm{bc}$ & $1.61 \mathrm{~d}$ & $27617 \mathrm{~cd}$ \\
\hline CODE F RZ & $0.166 \mathrm{a}$ & $0.107 \mathrm{a}$ & $416 \mathrm{a}$ & $1.58 \mathrm{~cd}$ & $24994 \mathrm{ab}$ \\
\hline CODE A RZ & $0.177 \mathrm{~cd}$ & $0.106 \mathrm{a}$ & $423 \mathrm{a}$ & $1.71 \mathrm{e}$ & $23512 \mathrm{ab}$ \\
\hline
\end{tabular}

${ }^{1}$ In column, values followed by different letters are significantly different at 0.05 .

TABLE 4: Quality parameters of heads from nine broccoli cultivars.

\begin{tabular}{lcccc}
\hline Cultivar & Granulometry & Compactness & Density & Internal leaves \\
\hline CHRONOS & $2.11 \mathrm{~b}^{1}$ & $1.61 \mathrm{de}$ & $0.189 \mathrm{ab}$ & $1.54 \mathrm{a}$ \\
NAXOS & $1.54 \mathrm{a}$ & $1.68 \mathrm{de}$ & $0.161 \mathrm{ab}$ & $1.50 \mathrm{a}$ \\
PHAROS & $1.48 \mathrm{a}$ & $1.42 \mathrm{bcd}$ & $0.183 \mathrm{ab}$ & $1.93 \mathrm{~cd}$ \\
GUEVARA & $1.34 \mathrm{a}$ & $1.11 \mathrm{a}$ & $0.196 \mathrm{ab}$ & $1.88 \mathrm{bcd}$ \\
ISI 14775 F1 & $1.31 \mathrm{a}$ & $1.30 \mathrm{abc}$ & $0.216 \mathrm{~b}$ & $1.81 \mathrm{bc}$ \\
ISI 14507 F1 & $1.49 \mathrm{a}$ & $1.18 \mathrm{ab}$ & $0.202 \mathrm{ab}$ & $1.72 \mathrm{~b}$ \\
CODE M RZ & $1.89 \mathrm{~b}$ & $1.51 \mathrm{cde}$ & $0.178 \mathrm{ab}$ & $1.90 \mathrm{~cd}$ \\
CODE F RZ & $2.72 \mathrm{c}$ & $1.47 \mathrm{cde}$ & $0.177 \mathrm{ab}$ & $1.89 \mathrm{~cd}$ \\
CODE A RZ & $2.44 \mathrm{c}$ & $1.46 \mathrm{cde}$ & $0.144 \mathrm{a}$ & $1.98 \mathrm{~d}$ \\
\hline
\end{tabular}

${ }^{1}$ In column, values followed by different letters are significantly different at 0.05 .

Other quality parameters of heads were shown in Table 4. Statistical analysis discriminates the different varieties in three subsets regarding bead size. The most suitable cultivars showed values below 1.54 (ISI14775 F1, ISI14507 GUEVARA, PHAROS, and NAXOS). CODE M RZ and CHRONOS showed acceptable values, but CODE F RZ and CODE A RZ do not have proper bead size. The bead size calculated is an average of the successive harvests. Increased bead sizes through time were observed in some cultivars. With regard to compactness, on a scale of $1-3$, the heads showed intermediate values of compactness from 1.11 (GUEVARA) to 1.68 (CHRONOS) as an average of all harvests. These values are acceptable to the marketing of cultivars. However dramatic changes in density values were recorded in the several harvests of some cultivars. In this context, further studies are needed to analyze both bead size and density head throughout the productive period.

The shape of the sprout was also analyzed. The results in Table 5 indicate that diameter average shows significant differences between several cultivars, ranging from $0.055 \mathrm{~m}$ (CODE F RZ) to $0.071 \mathrm{~m}$ (NAXOS). Height also presented significant differences between cultivars. While NAXOS showed the longer sprouts, CODE F RZ presented the shorter ones. When diameter/height ratio was close to the unit it 
TABLE 5: Agronomic characteristics of sprouts from nine broccoli cultivars.

\begin{tabular}{lccc}
\hline Cultivar & Diameter $(\mathrm{m})$ & Height $(\mathrm{m})$ & Diameter/height \\
\hline CHRONOS & $0.061 \mathrm{abc}$ & $0.060 \mathrm{c}$ & $0.961 \mathrm{a}$ \\
NAXOS & $0.071 \mathrm{~d}$ & $0.071 \mathrm{~d}$ & $1.004 \mathrm{ab}$ \\
PHAROS & $0.059 \mathrm{abc}$ & $0.056 \mathrm{ab}$ & $1.043 \mathrm{bcd}$ \\
GUEVARA & $0.066 \mathrm{c}$ & $0.058 \mathrm{ab}$ & $1.130 \mathrm{e}$ \\
ISI 14775 F1 & $0.065 \mathrm{bc}$ & $0.057 \mathrm{ab}$ & $1.134 \mathrm{e}$ \\
ISI 14507 F1 & $0.061 \mathrm{abc}$ & $0.057 \mathrm{ab}$ & $1.087 \mathrm{cde}$ \\
CODE M RZ & $0.059 \mathrm{ab}$ & $0.055 \mathrm{a}$ & $1.099 \mathrm{de}$ \\
CODE F RZ & $0.059 \mathrm{a}$ & $0.057 \mathrm{ab}$ & $1.026 \mathrm{abc}$ \\
CODE A RZ & $0.058 \mathrm{a}$ & $0.059 \mathrm{~b}$ & $0.990 \mathrm{ab}$ \\
\hline
\end{tabular}

In column, values followed by different letters are significantly different $(P<0.05)$.

TABLE 6: Pearson correlation coefficients $(r)$ between phenotypical variables and PCA scores shown in Figures 1 and 2.

\begin{tabular}{lcccc}
\hline Variables & & Nurseries & & \multicolumn{2}{c}{ Cultivars } \\
& First & Second & First & -0.28 \\
Days after transplanting & 0.89 & -0.04 & -0.59 & 0.74 \\
Diameter $(\mathrm{cm})$ & -0.27 & 0.52 & -0.30 & $0.93^{*}$ \\
Height $(\mathrm{cm})$ & -0.87 & 0.14 & $0.92^{*}$ & -0.41 \\
Granulometry & 0.29 & $-0.91^{*}$ & $-0.98^{*}$ & 0.43 \\
Head weight $(\mathrm{g})$ & -0.24 & $0.96^{*}$ & -0.31 & 0.53 \\
Compactness & -0.57 & 0.58 & 0.23 & 0.78 \\
Sprout diameter $(\mathrm{cm})$ & -0.54 & -0.32 & -0.03 & $0.90^{*}$ \\
Sprout height $(\mathrm{cm})$ & $-0.91^{1}$ & 0.00 & -0.87 \\
Internal leaves & $0.99^{*}$ & & &
\end{tabular}

${ }^{1}$ Statistically significant at 0.05 .

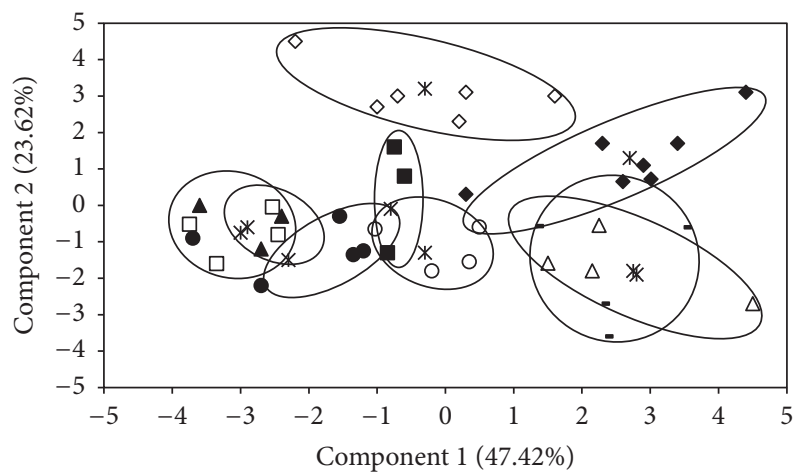
- CHRONOS
- ISI $14507 \mathrm{~F} 1$
O CODE M RZ
- PHAROS
- GUEVARA
$\triangle$ NAXOS
- CODE F RZ
ODE A RZ
$\square$ ISI $14775 \mathrm{~F} 1$

FIGURE 1: PCA plot showing the two major components of variability among the considered cultivars.

indicated that sprouts are spherical rather than elongated, which is a positive factor from the commercial standpoint. Statistical differences found between cultivars are shown in Table 5.

Principal component analysis was employed to analyze the relationship among the agronomic variables and the cultivars/commercial nurseries. Both first and second principal component explained more than $75 \%$ of the variance and

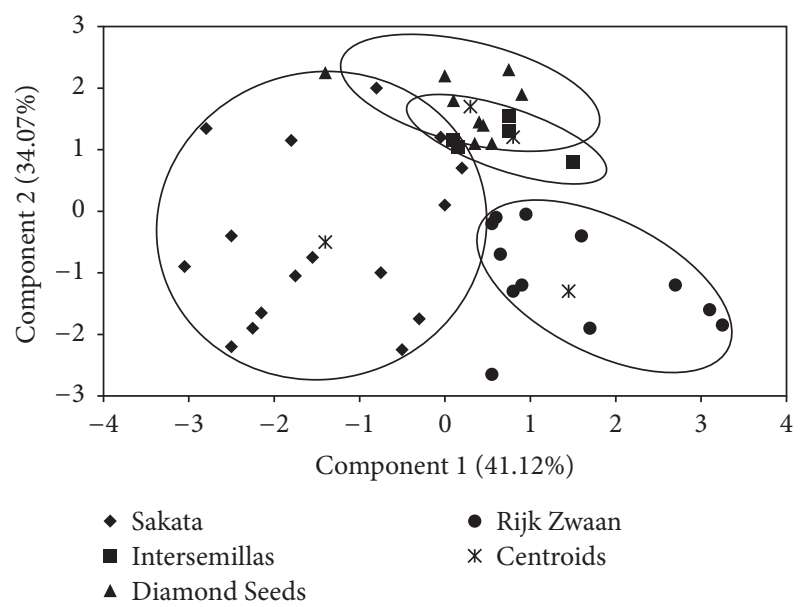

FIGURE 2: PCA plot showing the two major components of variability among the broccoli nurseries.

grouped data according to their cultivar and commercial origin (Figures 1 and 2). Individual correlations between the scores for the first and second components and the phenotypic variables above described, which characterize cultivars and nurseries, rented the values presented in Table 6. Regarding cultivars, the highest correlations were obtained between the scores for the first component and head weight, and for 
second component and head height $\left(r^{2}=0.98\right.$ and $0.93 P<$ 0.05 , resp.). When the correlation was performed between the scores for the first component and the phenotypic variable corresponding to the considered nurseries, the highest value was found with the presence of internal leaves $\left(r^{2}=0.99\right.$, $P<0.05)$. When correlated against the scores obtained for the second component, the highest values were found for granulometry and head weight.

\section{Conclusions}

Taken together, those results suggest that head weight and head height are the variables more responsible for the phenotypic differences found among the considered cultivars. The presence of internal leaves and granulometry and head weight also appear to be key traits defining each nursery. Additionally, multivariate analysis revealed that those cultivars from the same nursery share main common traits and, therefore, commercial origin is suggested to be strongly considered when breeding programs are designed.

\section{Conflicts of Interest}

The authors declare that there are no conflicts of interest regarding the publication of this paper.

\section{Acknowledgments}

This work was equally supported by CTAEX and Junta de Extremadura Grupos de Investigación GR15112, AGROS, GR15158, and FEDER funds. The authors thank Alberto Salguero Alarcón for reviewing the manuscript in English.

\section{References}

[1] J. W. Fahey, Y. Zhang, and P. Talalay, "Broccoli sprouts: An exceptionally rich source of inducers of enzymes that protect against chemical carcinogens," Proceedings of the National Academy of Sciences of the United States of America, vol. 94, no. 19, pp. 10367-10372, 1997.

[2] A. F. Brown, G. G. Yousef, E. H. Jeffery et al., "Glucosinolate profiles in broccoli: Variation in levels and implications in breeding for cancer chemoprotection," Journal of the American Society for Horticultural Science, vol. 127, no. 5, pp. 807-813, 2002.

[3] E. N. C. Renaud, E. T. Lammerts Van Bueren, J. R. Myers et al., "Variation in broccoli cultivar phytochemical content under organic and conventional management systems: Implications in breeding for nutrition," PLOS ONE, vol. 9, no. 7, Article ID e95683, 2014.

[4] G. J. Stables, A. F. Subar, B. H. Patterson et al., "Changes in vegetable and fruit consumption and awareness among US adults: Results of the 1991 and 19975 A Day for Better Health Program surveys," Journal of the American Dietetic Association, vol. 102, no. 6, pp. 809-817, 2002.

[5] E. Ordiales, J. I. Gutiérrez, L. Zajara, J. Gil, and M. Lanzke, "Assessment of utilization of sheep wool pellets as organic fertilizer and soil amendment in processing tomato and broccoli," Modern Agricultural Science and Technology, vol. 2, no. 2, pp. 20-35, 2016.

[6] D. K. Y. Tan, A. H. Wearing, K. G. Rickert, and C. J. Birch, "Broccoli yield production and quality can be determined by cultivar and temperature but not photoperiod in south-east Queensland," Australian Journal of Experimental Agriculture, vol. 39, pp. 901-909, 1999.

[7] H. T. Alrich, K. Salandanan, P. Kendall et al., "Cultivar choice provides options for local production of organic and conventionally produced tomatoes with higher quality and antioxidant content," Journal of the Science of Food and Agriculture, vol. 90, no. 15, pp. 2548-2555, 2010.

[8] M. W. Farnham and H. F. Harrrison, "Using self-compatible inbreeds of broccoli as seed producers," HortScience, vol. 38, pp. 85-87, 2003.

[9] R. Gray, "Broccoli Brassica oleracea L. (Italica group)," in Genetic Improvement of Vegetables Crops, G. Kalloo and B. O. Bergh, Eds., Pergamon Press, Oxford, 1993.

[10] B. Chung, "Effect of plant density on the sequential harvest yield of broccoli," Australian Journal of Experimental Agriculture, vol. 25, no. 4, pp. 959-962, 1985.

[11] Casar, L. M. Muñoz-Guerra, E. Ordiales, and J. López, "Efectos de fertilizantes con el inhibidor de la nitrificación 3, 4 dimetilpirazol fosfato en la producción, rentabilidad y calidad nutricional de un cultivo de brócoli," Jornadas de Horticultura, vol. 49, pp. 69-74, 2007.

[12] M. Boersma, A. J. Gracie, and P. H. Brown, "Relationship between growth rate and the development of hollow stem in broccoli," Crop and Pasture Science, vol. 60, no. 10, pp. 995-1001, 2009.

[13] C. J. Bakker, C. J. Swanton, and A. W. McKeown, "Broccoli growth in response to increasing rates of pre-plant nitrogen. I. Yield and quality," Canadian Journal of Plant Science, vol. 89, no. 3, pp. 527-537, 2009.

[14] C. Vidal-Aragón, M. Lozano, J. Bernalte et al., "Productive characteristics and volatile compounds of seven broccoli cultivars," Italian Journal of Food Science, vol. 21, no. 1, pp. 17-28, 2009.

[15] S. B. Sterrett, K. G. Haynes, and C. P. Savage Jr., "Cluster analyses on quality attributes identify broccoli cultivars suitable for early and main-season harvests on the Eastern Shore of Virginia," HortTechnology, vol. 14, no. 3, pp. 376-380, 2004.

[16] H. C. Kaymak, F. Yarali, and I. Guvenc, "Effect of transplant age on growth and yield of broccoli (Brassica oleracea var. italica)," Indian Journal of Agricultural Sciences, vol. 79, no. 12, pp. 972975, 2009.

[17] D. L. Schellenberg, A. D. Bratsch, and Z. Shen, "Large singlehead broccoli yield as affected by plant density, nitrogen, and cultivar in a pasticulture system," HortTechnology, vol. 19, pp. 792-795, 2009.

[18] S. Stamatiadis, M. Werner, and M. Buchanan, "Field assessment of soil quality as affected by compost and fertilizer application in a broccoli field (San Benito County, California)," Applied Soil Ecology, vol. 12, no. 3, pp. 217-225, 1999.

[19] S. B. Sterret, J. W. Mapp Jr., and C. W. Coale, "Feasibility of broccoli as a new enterprise. A systems approach," HortScience, vol. 25, pp. 638-641, 1990.

[20] S. B. Sterret, C. W. Coale Jr., and C. P. Savage Jr., "Comparison of managements techniques for broccoli production using a system approach," HortScience, vol. 26, pp. 599-602, 1991.

[21] S. J. Kays, "Preharvest factors affecting appearance," Postharvest Biology and Technology, vol. 15, no. 3, pp. 233-247, 1999. 




Scientifica
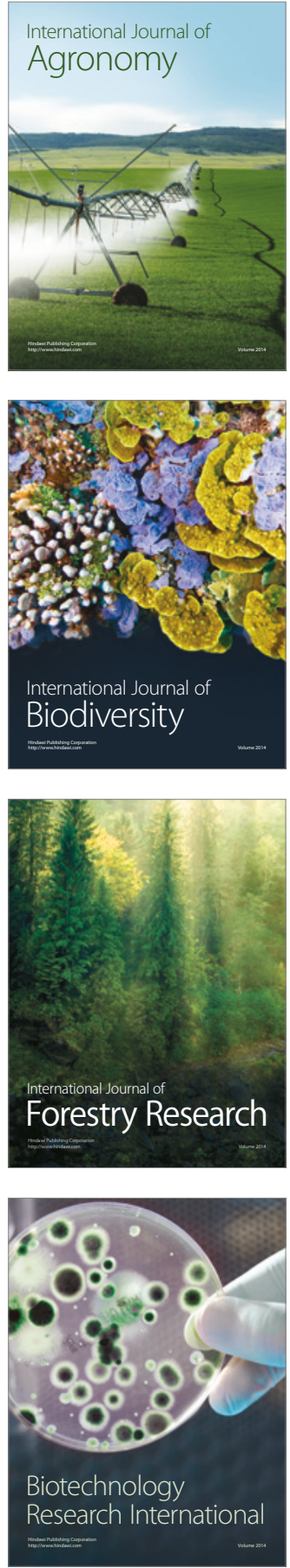
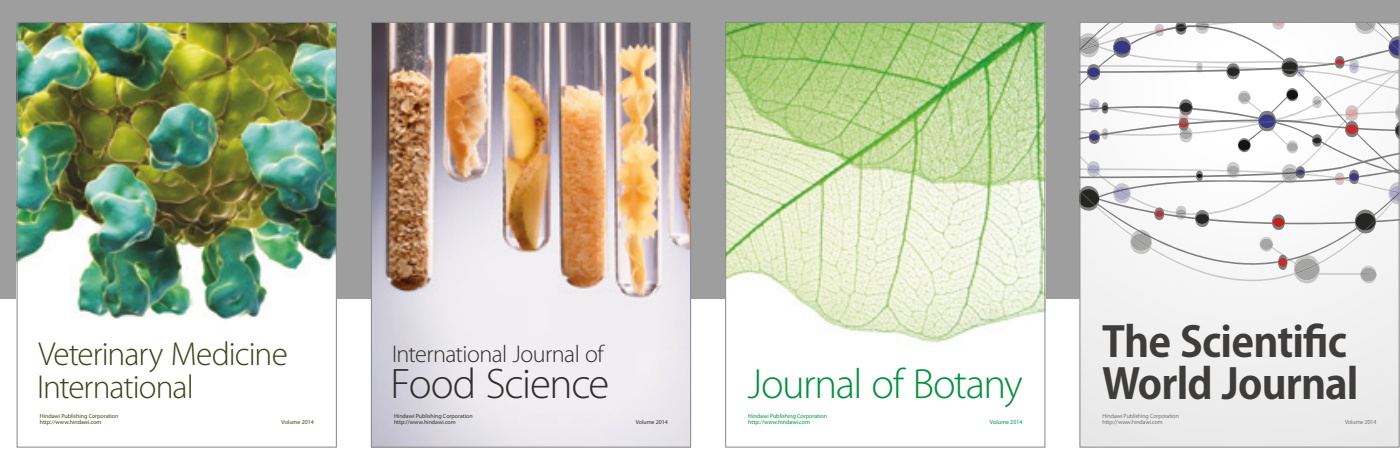

The Scientific

\section{World Journal}

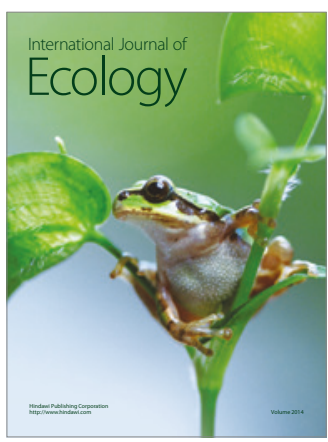

\section{Hindawi}

Submit your manuscripts at

https://www.hindawi.com
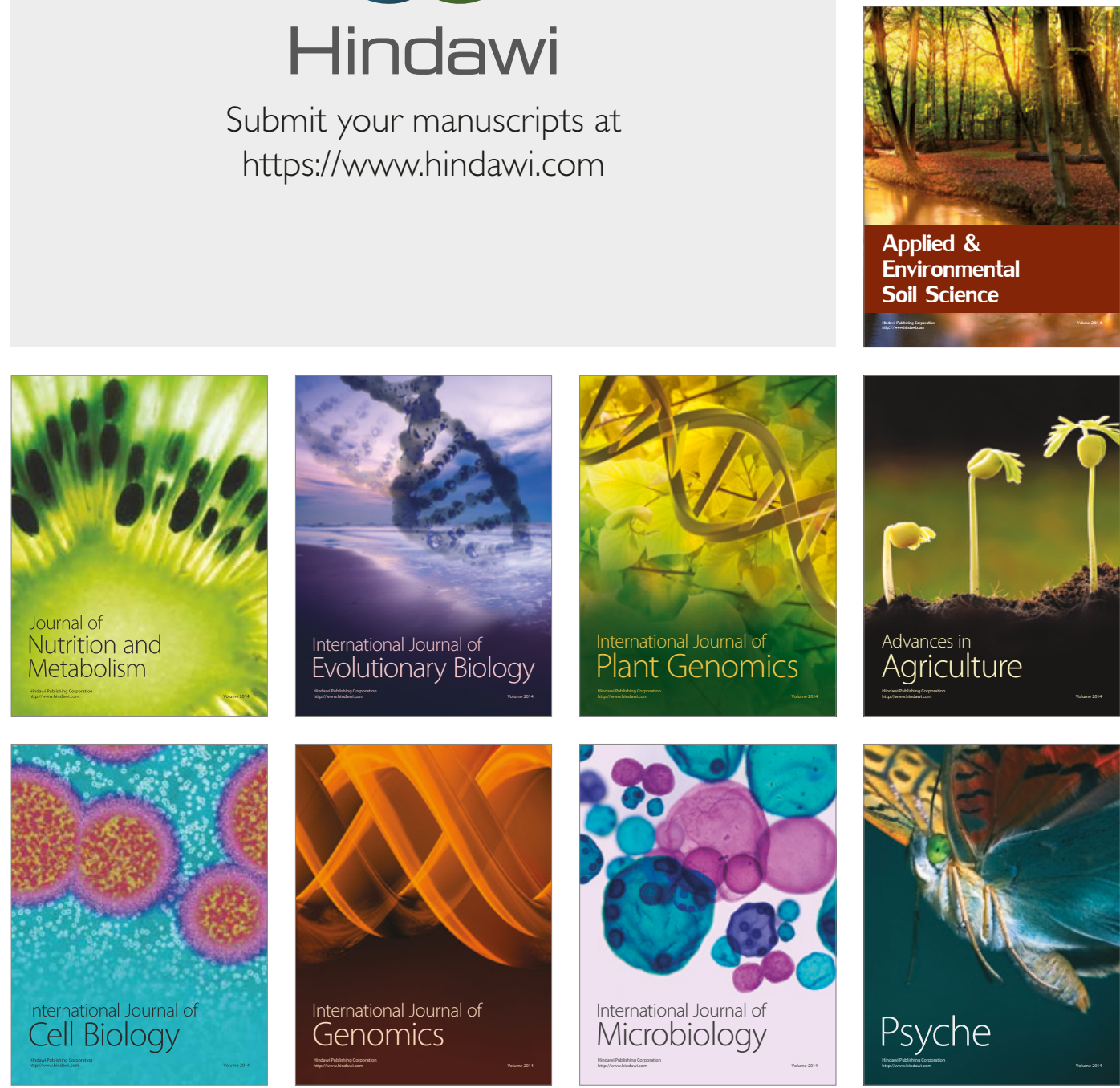

hternational Journal of Microbiology
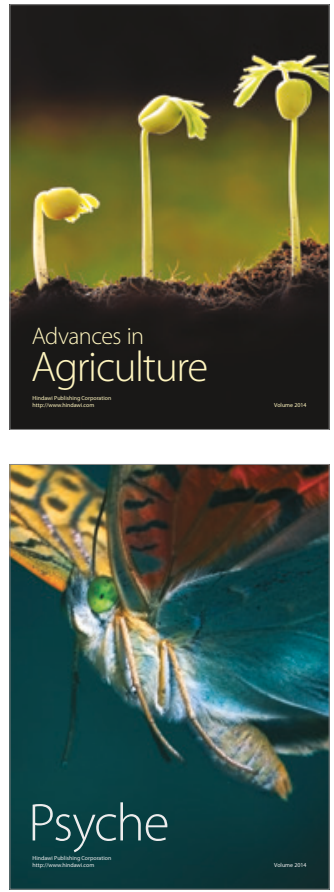